\title{
PERBEDAAN EFEKTIFITAS MADU DAN AIR GULA TERHADAP NYERI INJEKSI IMUNISASI CAMPAK BAYI USIA 9-15 BULAN PUSKESMAS LUBUK BUAYA TAHUN 2019
}

\author{
Dewi Susanti, Alsri Windra Doni, Rizqi Twin Desfialni Putri \\ (Politeknik Kesehatan Kemenkes Padang)
}

\begin{abstract}
Coverage of measles immunization in Padang city is $88.8 \%$, while the target of achieving national measles immunization is $95 \%$. The reason a child is not immunized is $27.5 \%$ because it is delayed at another time. Pain management of nonpharmacological immunization with honey and sugar water can increase comfort so as to avoid delaying at another time. The purpose of this study was to determine the differences in the effectiveness of honey and sugar water against the pain of measles immunization injection in infants aged 9-15 months. This type of research is a Quasi experiment with post test only design. sampling with a sample size of 32 people. Pain score data obtained from observation sheets and analyzed univariately and bivariately using an independent $t$ test with computerization. The results of the study mean the pain score in the honey group was 1.19 while the mean pain score in the sugar water group was 1.88. After an independent $t$ test was obtained $p$ value $=0.038(\alpha<0.05)$ means that there is a difference in the effectiveness of honey and sugar water against the pain of measles immunization injection. The results of the study concluded that honey was more effective on measles immunization injection pain scores. The suggestion of this study was to improve the comfort of children by minimizing the pain of immunization injection using honey and sugar water.
\end{abstract}

Keywords: honey; sugar water; injection pain

\section{PENDAHULUAN}

Menurut data dari ECDC (European Centre for Disease Prevention and Control) kasus campak di negara anggota Uni Eropa/EEA pada bulan Maret- Desember 2017 adalah 11.523 kasus sedangkan pada bulan Januari-Februari 2018 jumlah kasus campak adalah 2.569 kasus. Kasus tertinggi pada anak usia dibawah 1 tahun (393 kasus per milyar) dan

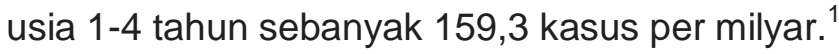

Upaya pengurangan kasus campak berdasarkan Peraturan Menteri Kesehatan RI No.42 Tahun 2013 melalui imunisasi.Imunisasi adalah upaya untuk meningkatkan kekebalan secara aktif terhadap suatu penyakit. Kementrian kesehatan melaksanakan Program Pengembangan Imunisasi (PPI) dalam menurunkan kejadian penyakit dengan imunisasi yaitu tuberkolosis, difteri, pertusis, campak, polio, tetanus dan hepatitis $\mathrm{B}^{2,3}$

Menurut data Riset Kesehatan Dasar (Riskesdas), Perkembangan cakupan imunisasi campak di Indonesia mengalami fluktuasi, tahun 2010 adalah $74,4 \%$, sedangkan pada tahun 2013 mengalami kenaikan sebesar 82,1\% dan pada tahun 2015 cakupan imunisasi campak tidak mengalami kenaikan yaitu tetap 82\% dan mengalami peningkatan pada tahun 2017 yaitu $89,9 \%$ namun kembali mengalami penurunan sebesar $77,3 \%$ pada tahun 2018 . Hal ini 
merupakan masalah serius yang dihadapi oleh Indonesia karena target imunisasi campak sebesar $95 \%{ }^{4,3,5}$.

Berdasarkan Profil Kesehatan Indonesia tahun 2017, provinsi dengan cakupan imunisasi campak terendah di Indonesia yaitu Maluku sebesar 63\%, Papua (65\%) dan Maluku Utara (69,0\%).Sedangkan provinsi Sumatera Barat berada pada posisi 12 terendah cakupan imunisasi campak di Indonesia (82,2\%).Cakupan imunisasi campak di Sumatera barat pada anak usia $<1$ tahun hanya $0,43 \%$ sedangkan pada anak usia 1-4 tahun hanya $0,41 \%{ }^{6}$

Berdasarkan Profil Kesehatan Sumatera Barat Tahun 2017 dari 19 kabupaten/kota hanya tiga kabupaten/kota yang mencapai target imunisasi campak yaitu Kabupaten Solok Selatan sebesar (100\%), kota Solok (99\%) dan Payakumbuh (96\%). Kota Padang masih belum mencapai target, cakupan imunisasi campak di kota Padang selama tiga tahun terakhirmulai dari tahun 2015 cakupan imunisasi campak sebesar 86,2\% dan mengalami kenaikan pada tahun 2016 yaitu 93,7 sedangkan cakupan imunisasi campak kembali menurun pada tahun 2017 yaitu $88,8 \%{ }^{6}$

Berdasarkan Profil Kesehatan Kota Padang tahun 2017, puskesmas dengan capaian cakupan imunisasi campak terendah adalah puskesmas Lubuk Buaya yaitu 66,6\% dan cakupan imunisasi campak berdasarkan laporan bulanan Puskesmas Lubuk Buaya dari bulan Januari sampai Agustus 2018 adalah 44,3\% ${ }^{7,8}$

Menurut data dari Riset Kesehatan Dasar (Riskesdas) 2013, persentase alasan anak tidak pernah diimunisasi adalah 26,3\% keluarga tidak mengizinkan, 28,8\% takut anak menjadi panas, 6,8\% anak sering sakit, 6,7\% tidak tahu tempat imunisasi dan 21,9\% tempat imunisasi jauh. Sedangkan alasan anak tidak pernah diimunisasi di Kota Padang adalah 14,6\% kurang menyadari kebutuhan imunisasi, 39,5\% takut efek samping imunisasi, 27,5\% menunda dilain waktu dan $17,2 \%$ karena desas-desus tentang imunisasi ${ }^{8,9}$.

Imunisasi merupakan tindakan umum yang dapat menjadi sumber rasa sakit pada anakanak.Prosedur yang menyakitkan selama tindakan imunisasi dapat menyebabkan anak mengalami gangguan mekanisme koping selama kunjungan berikutnya. Pengalaman yang baik selama imunisasi dapat meningkatkan kepercayaan orang tua atau keluarga, menghindari terjadinya kecemasan pada anak dan menghindari terjadinya keterlambatan terhadap jadwal imunisasi sehingga diperlukan strategi untuk mengelola rasa sakit/nyeri pada anak. ${ }^{10,11}$

Penanganan nyeri dapat dilakukan dengan manajemen nyeri farmakologis dan manajemen nyeri non farmakologis. Manajemen nyeri farmakologis terdiri atas pemberian analgesik opioid, analgesik non opioid dan anastesi topikal sedangkan manajemen nyeri non farmakologis untuk bayi dan anak usia 12-36 bulan yaitu kontak kulit ke kulit atau skin to 
skin contact (SSC), menyusui, posisi yang tepat saat imunisasi, kompres dingin \& panas dan rasa manis. ${ }^{12,13}$

Rasa manis memungkinkan proses mediasi rasa nyeri oleh aktivasi mekanisme opioid endogen. Peningkatan reseptor opioid dianggap sebagai hasil dari peningkatan kadar $\beta$ endorphin yang dapat mengurangi transmisi sinyal nyeri ke sistem saraf pusat.Air gula atau larutan sukrosa merupakan salah satu sumber rasa manis yang dapat diberikan sampai bayi usia 3 bulan atau lebih.

Madu juga merupakan sumber minuman yang mengandung rasa manis. Rasa manis pada madu tidak sama dengan gula, madu memiliki efek yang ringan dalam menaikkan gula darah.Kandungan senyawa oksidan dalam madu seperti asam askorbat, karotenoid, asam organik dan dapat menurunkan nyeri dengan mencegah terjadinya radikal bebas sehingga mengurangi kerusakan sel dan mengurangi tingkat peradangan yang merupakan sebab timbulnya rasa nyeri.Kandungan flavonoid pada madu dapat menghambat enzim cyclooxygenase (COX) agar tidak memproduksi prostaglandin sehingga zat mediator nyeri yaitu histamin akan berkurang. ${ }^{14,15,16}$

Penelitian yang dilakukan oleh Sekriptini (2013) menyimpulkan ada pengaruh pemberian madu terhadap penurunan skor nyeri akibat tindakan invasif pengambilan darah intravena pada anak di ruang unit gawat darurat Rumah Sakit Daerah (RSUD) Kota Cirebon. ${ }^{17}$

Hasil penelitian Christina, dkk (2015) menyimpulkan ada perbedaan rata- rata tingkat nyeri pada kelompok intervensi dan kelompok kontrol pada pemberian madu per oral terhadap penurunan nyeri imunisasi anak usia 2-18 bulan di Puskesmas Ngaliyan Semarang. ${ }^{18}$

Penelitian oleh Adesti,dkk (2016) menunjukkan ada pengaruh pemberian madu terhadap respon nyeri tindakan invasif.Sedangkan penelitian oleh Goenarwo, dkk (2011) menunjukkan madu dengan konsentrasi madu 50\% memiliki efek analgetik yang meningkat dibandingkan dengan madu dengan konsentrasi 25\% dan 100\% menunjukkan efek analgetik yang menurun ${ }^{19,20 .}$

Penelitian yang dilakukan oleh Jatana,dkk meniliti efek analgesia dari sukrosa atau larutan gula pada neonates, dengan membandingkan berbagai konsentrasi sukrosa $(10 \%$, $25 \%$ dan $50 \%$ ) dengan air dan ASI masing-masing sebanyak $1 \mathrm{ml}$ saat pengambilan sampel darah pada tumit. Pemberian ASI dan larutan sukrosa 10\% memiliki efek menurunkan respon fisiologis dan tingkah laku lebih rendah dibanding dengan konsentrasi sukrosa $25 \%$ dan sukrosa $50 \%{ }^{21}$

Perbedaan penelitian ini dengan penelitian sebelumnya adalah pada penelitian sebelumnya terdapat pada variabel independen dan karakteristik responden. Pada 
penelitian sebelumnya hanya meneliti satu variabel independen saja yaitu kelompok yang diberikan madu saja atau air gula saja dan usia responden bervariasi mulai dari bayi sampai usia balita.

\section{METODE PENELITIAN}

Penelitian ini merupakan penelitian dengan jenis eksperimen semu/quasi eksperimen dan desain post test only design.Disebut eksperimen semu karena pengelompokan anggota sampel pada kelompok eksperimen dan kelompok kontrol tidak dilakukan secara random atau acak dan disebut post test only design karena pengukuran penelitian tidak dilakukan sebelum intervensi, pengukuran hanya dilakukan setelah intervensi. ${ }^{22}$

Pada penelitian ini, diberikan dua buah perlakuan yaitu pemberian madu konsentrasi $50 \%$ pada kelompok perlakuan I dan air gula konsentrasi $50 \%$ pada kelompok perlakuan II. Pengukuran skala nyeri menggunakan lembar observasi FLACC (Face, Legs, Activity, Cry \& Consolability) setelah anak diimunisasi campak. Instrumen yang digunakan untuk menunjang penelitian ini adalah Lembar observasi yang berisi identitas responden dan skala perilaku nyeri FLACC (Face, Legs, Activity, Cry \& Consolability), Handphone. Populasi dalam penelitian ini adalah seluruh bayi di wilayah kerja Puskesmas Lubuk Buaya berjumlah 1326 bayi. Sampel dalam penelitian ini adalah bayi usia 9-15 bulan yang diimunisasi campak di Puskesmas Lubuk Buaya.

Teknik pengambilan sampel yang digunakan adalah non random sampling yaitu pengambilan sampel bukan secara acak dengan jenis purposive sampling. Pengambilan sampel secara purposive sampling didasarkan pada suatu pertimbangan yang dibuat sendiri oleh peneliti berdasarkan ciri atau sifat-sifat populasi yang sudah diketahui sebelumnya.

\section{HASIL PENELITIAN}

Penelitian ini bertujuan untuk mengetahui perbedaan efektifitas madu dan air gula terhadap skor nyeri injeksi imunisasi campak pada bayi usia 9-15 bulan di Puskesmas Lubuk Buaya. Responden yang terpilih menjadi sampel pada penelitian ini adalah 32 orang dengan 16 orang pada kelompok madu dan 16 orang pada kelompok air gula. Dari hasil penelitian, maka didapatkan data sebagai berikut :

Tabel 1. Rerata skor nyeri injeksi imunisasi campak pada bayi yang diberikan madu sebelum imunisasi di Puskesmas Lubuk Buaya Tahun 2019

\begin{tabular}{cccccc}
\hline Madu & $\mathrm{N}$ & Mean & SD & Min & Max \\
\cline { 2 - 5 } & 16 & 1,19 & 0,911 & 0 & 3 \\
\hline
\end{tabular}


Tabel 1 menunjukkan bahwa rerata skor nyeri pada bayi yang diberikan madu sebelum imunisasi yaitu 1,19 . Standar deviasi nya 0,911 dengan nilai minimum nyeri 0 dan nilai maksimum 3.

Tabel 2. Rerata skor nyeri injeksi imunisasi campak pada bayi yang diberikan air gula sebelum imunisasi di Puskesmas Lubuk Buaya Tahun 2019

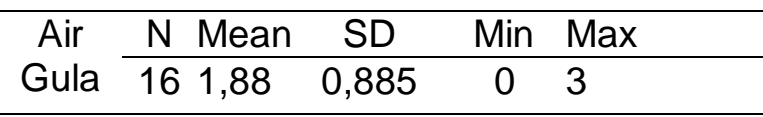

Tabel 2 menunjukkan bahwa rerata skor nyeri imunisasi pada bayi yang diberikan air gula sebelum imunisasi yaitu 1,88 . Standar deviasi nya 0,885 dengan nilai minimum nyeri 0 dan nilai maksimum 3.

Tabel 3 Perbedaan efektivitas madu dan air gula terhadap skor nyeri injeksi imunisasi campak pada Tahun 2019

\begin{tabular}{cccccc}
\hline Intervensi & $\mathrm{N}$ & Mean & $\begin{array}{c}\text { Standar } \\
\text { deviasi }\end{array}$ & Nilai t & $\begin{array}{c}\text { Sig. } \\
\text { (2-tailed) }\end{array}$ \\
\cline { 1 - 4 } Madu & 16 & 1,19 & 0,911 & -2.166 & 0,038 \\
\hline Air Gula & 16 & 1,88 & 0,885 & & \\
\hline Total & 32 & & & & \\
\hline
\end{tabular}

Tabel 3 diketahui nilai mean madu adalah 1,19 dengan standar deviasi 0,911 dan nilai mean air gula adalah 1,88 dengan standard deviasi 0,885 . Nilai $p=0,038$ ( $p$ value $<0,05$ ) yang artinya ada perbedaanefektivitas madu dan air gula terhadap nyeri injeksi imunisasi campak di Puskesmas Lubuk Buaya Tahun 2019.

\section{PEMBAHASAN}

\section{A. Rerata skor nyeri injeksi imunisasi campak pada bayi yang diberikan madu sebelum imunisasi di Puskesmas Lubuk Buaya Tahun 2019}

Hasil penelitian dari 16 responden yang diberikan madu menunjukkan rerata skor nyeri pada bayi yang diberikan madu sebelum imunisasi adalah 1,19 atau mengalami nyeri ringan dengan skor terendah 0 (tidak nyeri) dan skor tertinggi 3 (nyeri berat). Penelitian ini sejalan dengan penelitian yang dilakukan oleh Handayani,dkk (2015) dengan membandingkan skor nyeri pada 40 responden kelompok kontrol dan 40 responden kelompok madu usia 2 bulan1 tahun yang mendapatkan imunisasi dengan penilaian skor nyeri menggunakan skala nyeri FLACC menunjukkan rerata tingkat nyeri kelompok madu adalah 2,47 yaitu mengalami nyeri ringan sedangkan rerata tingkat nyeri kelompok kontrol adalah 3,00 yaitu mengalami nyeri ringan. Meskipun begitu, hal ini menunjukkan ada penurunan rerata skor nyeri dari 3,00 menjadi $2,47 .^{19}$ 
Penelitian ini sebanding dengan penelitian yang dilakukan oleh Pebriani, SH (2018) pada anak usia 1-6 tahun yang dilakukan tindakan invasif berupa pemasangan infus dengan melihat perbedaan skor nyeri pada kelompok madu dan kelompok kontrol dimana sampel dibagi menjadi 2 kelompok yaitu 17 responden mendapatkan madu dan 17 responden tidak mendapatkan madu, penilaian skor nyeri menggunakan CHEOPS dimana skor 4 berarti tidak ada nyeri dan skor 13 berarti nyeri berat, menunjukkan bahwa rerata skor nyeri pada kelompok madu adalah 3,00 atau mengalami nyeri ringan dengan skor terendah 4 dan skor tertinggi 13 sedangkan rerata skor nyeri pada kelompok kontrol adalah 8,00 atau mengalami nyeri sedang dengan skor terendah 6 dan skor tertinggi 13.

Penelitian ini tidak sejalan dengan penelitian yang dilakukan oleh Sekriptini (2013) dengan melihat pengaruh madu dalam menurunkan nyeri pada anak usia 1-3 tahun saat tindakan invasif pengambilan darah di RSUD Gunung Jati dimana jika pengambilan darah tidak berhasil pada responden,maka akan dilakukan pengulangan suntikan/injeksi dengan diistirahatkan dulu selama 5 menit kemudian dilakukan pemberian ulang madu 2 menit sebelum pengambilan darah menunjukkan bahwa rerata skor nyeri pada kelompok madu adalah 8,8 atau mengalami nyeri sedang dengan skor terendah 5 dan skor tertinggi 13 . Sedangkan rerata skor nyeri pada kelompok kontrol adalah 11 atau mengalami nyeri berat dengan skor terendah adalah 6 dan skor tertinggi adalah 13.Dari estimasi diyakini bahwa rerata skor nyeri kelompok madu berada diantara 8,20 sampai dengan 9,49 (nyeri sedang) sedangkan rerata skor nyeri kelompok kontrol diyakini berada antara 9,78 sampai dengan 11,33 (nyeri berat). Akan tetapi, penelitian ini menunjukkan ada penurunan rerata skor nyeri pada kelompok madu ${ }^{17}$.

Hal ini kemungkinan disebabkan oleh kandungan senyawa pada madu adanya senyawa oksidan seperti asam askorbat, karoten, asam organik, asam amino dan protein dalam madu mencegah terjadinya radikal bebas sehingga mengurangi kerusakan sel dan mengurangi tingkat peradangan yang merupakan sebab timbulnya rasa nyeri. Kerusakan jaringan subkutis ini memicu pelepasan prostaglandin dengan bantuan enzim cyclooxygenase (COX) dari asam arakhidonat. Kandungan flavonoid pada madu menghambat enzim COX maka memblokade prostaglandin sehingga zat mediator nyeri yaitu histamine akan berkurang. Adanya glukosa dan fruktosa pada madu juga menghasilkan rasa manis yang merangsang serabut di dorsal horn, batang otak dan jaringan perifer mengeluarkan neuromodulator berupa endorphine. Endorphine menghambat pelepasan substansi $P$ sehingga nyeri akan berkurang. ${ }^{15,16,17}$

Rerata skor nyeri 16 bayi yang diberikan madu adalah 1,19 atau mengalami nyeri ringan namun sebanyak 5 orang $(31,25 \%)$ mengalami nyeri sedang. Peneliti berasumsi hal ini berkaitan dengan usia responden. Dari 5 responden yang mengalami nyeri sedang 
seluruhnya (100\%) berusia 11 bulan. Perkembangan usia anak mempengaruhi makna nyeri dan ekspresi yang dimunculkan. Anak dengan usia yang lebih tua cendrung bereaksi dengan kemarahan emosional yang kuat dan cenderung lebih gelisah dalam merespon nyeri yang ia rasakan sehingga saat penilaian respon perilaku nyeri yang melihat reaksi wajah, kaki dan menangis menunjukkan total skor nyeri yang lebih besar dibandingkan pada anak dengan usia yang lebih muda.

Peneliti juga berasumsi sebagian besar respoden setelah diberikan madu hanya menunjukkan respon merintih meskipun ada yang menangis namun dapat segera diam dan tenang. Sebagian besar orang tua responden tidak mengetahui madu dapat mempengaruhi respon nyeri injeksi/suntikan imunisasi. Orang tua responden hanya mengetahui manfaat madu baik untuk kesehatan tubuh anaknya dan dapat dijadikan suplemen untuk penambah nafsu makan anak selain itu madu pun mudah didapat, sehingga madu kedepannya dapat dijadikan pilihan untuk mengatasi nyeri injeksi/suntikan baik injeksi imunisasi maupun tindakan invasif lainnya pada anak seperti pemasangan infus dan pengambilan darah intravena. Kandungan yang ada di dalam madu seperti Flavonoid dapat menghambat enzim COX sehingga nyeri berkurang selain itu kandungan asam askorbat dan karoten pada madu mencegah terjadinya radikal bebas sehingga mengurangi rasa nyeri ditambah lagi rasa manis pada madu merangsang reseptor alami di otak untuk mengeluarkan endorphin sehingga nyeri pun akan berkurang. Diharapkan madu dapat dijadikan alternatif pengobatan non-farmakologis dalam mengurangi nyeri injeksi sehingga mengurangi tingkat kecemasan dan meningkatkan kenyamanan bagi anak.

\section{B. Rerata skor nyeri injeksi imunisasi campak pada bayi setelah diberikan air gula di Puskesmas Lubuk Buaya Tahun 2019}

Hasil penelitian dari 16 responden yang diberikan air gula didapatkan rerata skor nyeri pada bayi yang diberikan air gula sebelum imunisasi adalah 1,88 atau mengalami nyeri sedang dengan skor terendah 0 (tidak nyeri) dan skor tertinggi 3 (nyeri berat). Penelitian ini sejalan dengan penelitian yang dilakukan oleh Minarti,dkk (2010) pada bayi usia 2-12 bulan yang mendapatkan imunisasi DPT-HB di Puskesmas Denpasar Timur dimana penilaian skor nyeri menggunakan skala FLACC menunjukkan rerata intensitas nyeri pada kelompok air gula adalah 5,30 atau mengalami nyeri sedang dengan rentang skor nyeri 4,26- 5,98 sedangkan rerata intensitas nyeri pada kelompok kontrol adalah 8,25 atau mengalami nyeri berat dengan rentang skor nyeri 7,99-8,11. Hasil ini menunjukkan bahwa pemberian sukrosa/air gula mampu menurunkan intensitas nyeri menjadi 5,30 dari rerata 8,25 dengan selisih penurunan sebesar $2,95 .^{23}$

Penelitian ini juga sejalan dengan penelitian yang dilakukan oleh Susilaningsih,dkk (2016) di Puskesmas Sukoharjo yang dilakukan pada bayi yang diimunisasi pentabio 
dengan penilaian dilakukan pada sesaat setelah injeksi, 2 menit dan 5 menit setelah imunisasi menunjukkan rerata respon nyeri sesaat setelah injeksi pada kelompok air gula adalah 5,45 (nyeri sedang) dengan skor minimal 3 dan skor maksimal 8 dan menunjukkan hasil yang menurun pada 2 Menit dan 5 menit setelah imunisasi dengan rerata masingmasing 2,15 (nyeri ringan) dan 1,10 sedangkan pada kelompok kontrol rerata respon nyeri sesaat setelah imunisasi adalah 8,95 (nyeri berat) dan menunjukkan hasil yang menurun pada 3 menit dan 5 menit setelah imunisasi dengan rerata masing-masing 7,45 dan 6,95.24

Penelitian ini yang dilakukan oleh Clara,lita (2015) melibatkan 20 responden dari kelompok air gula dan 20 responden kelompok kontrol, penilaian skor nyeri menggunakan skala FLACC menunjukkan rerata respon nyeri pada kelompok air gula pada sesaat setelah injeksi adalah 8,65 atau mengalami nyeri berat sedangkan pada 3 menit dan 5 menit setelah imunisasi rerata skor nyeri masing-masing 2,15 dan 1,10 atau mengalami nyeri ringan sedangkan pada kelompok kontrol rerata skor nyeri setelah injeksi adalah 8,95 atau mengalami nyeri berat sedangkan pada 3 menit dan 5 menit setelah imunisasi rerata skor nyeri masing-masing 7,45 dan 6,95 atau mengalami nyeri sedang. Penelitian ini menunjukkan penurunan rerata skor nyeri pada kelompok air gula. ${ }^{25}$

Hal ini kemungkinan disebabkan karena air gula yang diteteskan pada mulut bayi merangsang lidah sebagai indera pengecap menafsirkan rasa. Rasa tersebut akan ditafsirkan oleh otak, setelah itu akan terjadi preabsorbsi rasa manis yang dapat merangsang reseptor syaraf asenden, dimana rangsangan tersebut akan dikirim ke hipotalamus melalui spinal cord ke bagian batang otak ke bagian otak dan thalamus melalui jaras spinotalamikus. Jaras spinotalamikus memungkinkan pengiriman nyeri melalui alur syaraf desenden yang mengeluarkan endorphin.Endorphinmenghambat pelepasan substansi $\mathrm{P}$ sehingga nyeri akan berkurang/menurun. ${ }^{13,26}$

Rerata skor nyeri 16 bayi yang diberikan air gula adalah 1,88 atau mengalami nyeri sedang namun sebanyak 4 orang (25\%) mengalami nyeri berat. Peneliti berasumsi hal ini terjadi berkaitan dnegan jenis kelamin responden.Dari 4 orang responden seluruhnya $(100 \%)$ berjenis kelamin perempuan.Saat merespon nyeri, anak laki-laki lebih dapat mentoleransi rasa nyeri dibandingkan anak perempuan.Setelah diberikan air gula, sebagian besar orang tua responden beranggapan mengkonsumsi air gula tidak memiliki manfaat Bagi kesehatan anak. bahkan orang tua beranggapan konsumsi gula dapat mengakibatkan karies pada anak. Hal tersebut tidak sepenuhnya salah, konsumsi air gula dengan konsentrasi yang tepat dapat menjadi alternatif bagi anak dalam mengurangi nyeri injeksi/suntikan. Selain itu air gula mudah didapatkan dalam kehidupan sehari- hari dengan harga yang sangat terjangkau. 


\section{Perbedaan efektivitas madu dan air gula terhadap skor nyeri injeksi imunisasi campak}

Hasil penelitian pada kedua kelompok menunjukkan adanya perbedaan efektifitas madu dan air gula terhadap nyeri injeksi imunisasi campak. Berdasarkan hasil uji statistik didapatkan nilai $p=0,038$ ( $p$ value $<0,05$ ) yang artinya terdapat perbedaan efektifitas madu dan air gula terhadap nyeri injeksi imunisasi campak.

Hasil penelitian yang dilakukan oleh Handayani,dkk tahun 2015 yang berjudul "Pengaruh Pemberian Madu dalam Menurunkan Tingkat Nyeri Pada Bayi Usia 2-18 bulan yang Dilakukan Imunisasi Di Puskesmas Ngaliyan Semarang menunjukkan bahwa mengkonsumsi madu dapat menurunkan nyeri imunisasi pada bayi dengan $p=0,005$. Selain itu, hasil penelitian dari Pratiwi,dkk tahun 2016 juga menunjukkan bahwa mengkonsumsi madu dapat menurunkan respon nyeri anak usia sekolah yang dilakukan tindakan invasif dengan $p=0,001$ sehingga dapat disimpulkan bahwa madu memiliki pengaruh dalam menurunkan respon nyeri.

Penelitian serupa pada kelompok air gula juga menunjukkan pengaruh air gula terhadap respon nyeri yaitu penelitian yang dilakukan oleh Clara tahun 2015 yang berjudul "Pengaruh Intervensi Glukosa Oral Terhadap Respon Nyeri Pada Bayi yang dilakukan imunisasi pentavalen di Puskesmas Baki Sukoharjo menunjukkan bahwa mengkonsumsi air gula dapat menurunkan nyeri imunisasi pada bayi dengan $p=0,001$. Selain itu, hasil penelitian dari Susilaningsih,dkk tahun 2016 menunjukkan bahwa mengkonsumsi air gula dapat menurunkan respon nyeri imunisasi dengan $p=0,03$ sehingga dapat disimpulkan bahwa air gula memiliki pengaruh dalam menurunkan respon nyeri imunisasi.

Madu adalah cairan kental yang dihasilkan oleh lebah madu. Di dalam $100 \mathrm{ml}$ madu terdapat terdapat kadar glukosa $31 \%$, enzim, mineral \& vitamin $0,5 \%$, asam $43,1 \%$ dan flavonoid 0,006\%. Kandungan glukosa pada madu menghasilkan rasa manis yang merangsang serabut di dorsal horn, batang otak dan jaringan perifer mengeluarkan neuromodulator yang menghambat transmisi impuls nyeri sehingga nyeri yang dirasakan berkurang. Selain itu kandungan flavonoid pada madu juga memiliki fungsi memblok terbentuknya prostaglandin sehingga zat mediator nyeri yaitu histamin akan berkurang. Senyawa oksidan seperti asam askorbat, karoten, asam organik memiliki sifat antioksidan yang berfungsi mencegah radikal bebas selama fase inflamasi yang merupakan penyebab utama nyeri. ${ }^{15,16,18}$

Sama halnya dengan madu, air gula juga mempengaruhi respon nyeri injeksi imunisasi. Kandungan sukrosa atau gula merangsang peningkatan anti nyeri alami dalam tubuh melalui mekanisme opioid endogen. Serabut di dorsal horn batang otak dan jaringan perifer mengeluarkan neuromodulator yang menghambat aksi neuron yang mentransmisikan 
impuls nyeri. Bahkan, jika impuls nyeri dihantarkan ke otak, terdapat pusat korteks yang memodifikasi nyeri sehingga nyeri akan berkurang. ${ }^{27,28}$

Asumsi peneliti, jika dilihat dari selisih rerata kelompok madu dan air gula didapatkan rerata skor nyeri madu 0,69 lebih rendah daripada rerata skor nyeri air gula. Peneliti berasumsi hal ini berkaitan dengan komposisi yang terdapat pada madu dan air gula meskipun pada penelitian madu dan air gula dibuat dalam konsentrasi larutan yang sama yaitu 50\% namun madu dan air gula masing-masing memiliki komposisi yang mempengaruhi respon nyeri seperti pada madu terdapat flavonoid, glukosa,enzim dan asam sedangkan pada air gula hanya glukosa selain itu waktu penilaian respon nyeri mempengaruhi rerata skor nyeri. Penilaian respon nyeri yang dilakukan pada 3-5 menit setelah imunisasi menunjukkan penurunan rerata skor nyeri yang lebih tinggi.

Oleh karena itu diharapkan madu dan air gula dapat digunakan sebagai alternatif terhadap respon nyeri karena sangat mudah didapatkan pada kehidupan sehari-hari, madu juga memiliki beberapa manfaat selain sebagai penanganan nyeri nonfarmakologis juga bisa digunakan untuk tambahan energi, menambah kadar haemoglobin dll.

\section{SIMPULAN DAN SARAN}

Berdasarkan hasil analisis data dan pembahasan dapat disimpulkan bahwa Ada perbedaan efektifitas madu dan air gula terhadap nyeri imunisasi campak dengan $p=0,038$ ( $p$ value $<0,05$ ) dimana Rerata skor nyeri injeksi imunisasi pada bayi usia 9-15 bulan yang diberikan madu sebelum imunisasi di Puskesmas Lubuk Buaya tahun 2019 adalah 1,19 dengan nilai minimum nyeri 0 dan nilai maksimum 3 sedangkan Rerata skor nyeri injeksi imunisasi pada bayi usia 9-15 bulan yang diberikan air gula sebelum imunisasi di Puskesmas Lubuk Buaya tahun 2019 adalah 1,88. dengan nilai minimum nyeri 0 dan nilai maksimum 3.

Disarankan Memberikan konseling kepada orang tua tentang pentingnya meningkatkan kenyamanan pada anak saat imunisasi dengan meminimalkan rasa nyeri imunisasi dengan pemberian madu dan air gula. Dan Memberikan konseling kepada orang tua pentingnya anak untuk diimunisasi campak sesuai dengan jadwal imunisasi.

\section{DAFTAR PUSTAKA}

1. ECDC. Surveilance Report Monthly measles and rubella monitoring report. https://ecdc.europa.eu/sites/portal/files/documents/Mont hly-Measles- Rubellamonitoring-report-July-2018-1.pdf. Published 2018.

2. Menteri Kesehatan Republik Indonesia. Peraturan Menteri Kesehatan RI Nomor 42 Tahun 2013. indonesia; 2013.

3. Badan Penelitian dan Pengembangan Kesehatan. Riset Kesehatan Dasar 2013. Ris 
Kesehat Dasar 2013. 2013.

4. Kemenkes RI. Data dan Informasi profil Kesehatan Indonesia 2018. Data dan Inf Profil Kesehat Indones. 2018.

5. Riskesdas 2018. Riskesdas 2018. Kementrian Kesehat Republik Indones. 2018. doi:1 Desember 2013

6. Dinas Kesehatan Kota Padang. Profil Kesehatan Kota Padang Tahun 2017. Dinas Kesehat Kota Padang. 2017.

7. Dinas Kesehatan Kota Padang. Laporan Tahunan Tahun 2017 Edisi 2018. Padang; 2018.

8. Puskesmas Lubuk Buaya. Laporan Bulanan Hasil Imunisasi Rutin Bayi. Padang; 2018.

9. Yunis T;Wahyono M. Peningkatan cakupan dan mutu imunisasi. http://www.depkes.go.id/resources/download/info-terkini/ materi pra rakerkesnas 2018/Pakar Imunisasi.pdf. Published 2017.

10. Judha M, Sudarti;Fauziah A. Teori Pengukuran Nyeri \& Nyeri Persalinan. In: Pustaka Cendekia:Yogyakarta. ; 2012. doi:10.1007/s00520-011-1327-1

11. Stevens KE, Marvicsin DJ. Evidence-based recommendations for reducing pediatric distress during vaccination. Pediatr Nurs. 2016.

12. Ghofur A ;Mardalena I. Effect of Glucose on the Response Pain Baby in Puskesmas Gamping li Sleman Yogyakarta. Yogyakarta; 2014.

13. Fattori R, Buttazzi K R. Prevention and Management of Procedural Pain in the Neonate.; 2010.

14. Yuliarti. N. Khasiat madu untuk kesehatan dan kecantikan. 2015.

15. Putri NA, Asparini RR. PERAN MADU DALAM MENGHAMBAT PERTUMBUHAN BAKTERI PADA LUKA BAKAR. Saintika Med. 2017. doi:10.22219/sm.v13i2.5413

16. Alvarez-Suarez JM, Tulipani S, Romandini S, Bertoli E, Battino M. Contribution of honey in nutrition and human health: A review. Med J Nutrition Metab. 2010. doi:10.1007/s12349-009-0051-6

17. Sekriptini AY. Pengaruh pemberian madu terhadap penurunan skor nyeri akibat tindakan invasif pengambilan darah intra vena pada anak di ruang UGD RSUD Kota Cirebon. Program. 2013. doi:10.1130/0091-7613(1983)11<643

18. Handayani CU, Alfiyanti D, Nurullita U. Pengaruh Pemberian Madu Dalam Menurunkan Tingkat Nyeri Pada Bayi Usia 2-18 Bulan Yang Dilakukan Inunisasi Di Puskesmas Ngaliyan Semarang. J Ilmu Keperawatan dan Kebidanan. 2016.

19. Pratiwi AR, Lutfiyati A, Yati D. PENGARUH PEMBERIAN MADU TERHADAP RESPON NYERI ANAK USIA SEKOLAH YANG DILAKUKAN TINDAKAN INVASIF DI 
RSUD WATES KULON PROGO. Media IImu Kesehat. 2016.

doi:10.30989/mik.v5i3.170

20. Edijanti G, Chodidjah SH. Uji Efektifitas Analgetik Madu pada Tikus dengan Metoda Geliat Asetat. Univ Islam Sultan Agung. 2011.

21. Jatana SK, Dalal SS, Wilson CG. Analgesic effect of oral glucose in neonates. Med J Armed Forces India. 2003. doi:10.1016/S0377-1237(03)80048-5

22. Notoadmojo S. Metodologi Penelitian. Jakarta: Rineka Cipta; 2013.

23. Minarti N made aries, Pande. Pengaruh Pemberian Oral Sukrosa Terhadap Intensitas Nyeri Saat Imunisasi DPT-HB Pada Bayi Di Puskesmas II Denpasar Timur. Bali; 2010.

24. Susilaningsih Endang Zulaikha, Sulastri;Clara Lita Andes. Pengaruh Intevensi Glukosa Oral 30\% Terhadap Respon Nyeri Bayi dengan Imunisasi di Puskesmas Baki Sukoharjo. Univ Muhammadiyah Surakarta. 2016.

25. Clara LA. Pengaruh Pemberian Glukosa Oral 40\% Terhadap Respon Nyeri Pada Bayi yang Dilakukan Imunisasi Pentavalen di Puskesmas Baki Sukoharjo. Univ Muhammadiyah Surakarta. 2015.

26. Kassab M, Anabrees J, Harrison D, Wadah K CS. Sweet Taste Drinks Effects on Reducing Injection Pain and Associated Stress among Infants: A Meta-Analysis of Randomized Controlled Trials. Open J Pediatr Neonatol. 2017.

27. Prabandari GM, Musthofa SB, Kusumawati A. Beberapa faktor yang berhubungan dengan penerimaan ibu terhadap imunisasi Measles Rubella pada snak SD di Desa Gumpang. J Kesehat Masy. 2018.

28. Sherwood L. Membran Plasma dan Potensial Membran. Fisiol Mns dari sel ke Sist. 2012. doi: $10.1145 / 2566486.2567983$ 